\title{
Association of PIT-1 gene polymorphism with birth weight, milk and reproduction traits in Isfahan Holstein cows (Brief Report)
}

\section{Beziehungen zwischen dem PIT-1 Genpolymorphismus und dem Geburtsgewicht sowie Milch- und Reproduktionsmerkmalen bei Isfahan Holstein Kühen}

MOHAMMAD ALI EDRISS, VAHID EDRISS and HAMID REZA RAHMANI

Department of Animal Science, College of Agriculture, Isfahan University of Technology, Isfahan, Iran

\section{Background}

Pit-1 (POU1F1) is a member of the POU-domain family of genes that play important regulatory roles in developmental processes (DYBUS et al. 2004). Pit-1, an approximate 33-kilodalton protein (291 amino acid), was first associated with a critical role in the transcriptional regulation of growth hormone $(\mathrm{GH})$ and prolactin (PRL) genes (DYBUS et al. 2003). Molecular basis of this polymorphism was the silent mutation $(G \rightarrow A)$ located within exon 6 of the Pit-1 gene (DIERKES et al. 1998). Pit-1 gene considered as a candidate marker for milk production due to regulation of expression of bGH and the prolactin genes which are essential for mammary gland development and milk yield (DYBUS et al. 2004).

\section{Material and methods}

Genomic DNA samples were obtained in summer 2006 from 268 Holstein dairy cows belonging to four different herds. Animals were between 3 to 6 years of age. Genomic data along with 2588 related production and reproduction traits records (birth weight, milk yield, fat and protein percentage, pregnancy length, days in milk, open days and dry days) were used in statistical analysis. DNA samples were extracted from whole blood. PCR conditions described by EDRISS et al. (2008). Polymorphic variants of the Pit-1 gene on recorded traits were analysed using SAS package (SAS 2003). The following model was employed:

$$
Y_{i j k}=\mu+G_{i}+H_{j}+b\left(x_{i j k}-C l\right)+e_{i j k}
$$

where $Y_{i j k}$ is the analysed trait (milk and reproductive traits), $\mu$ the overall mean; $G_{i}$ the fixed effect of the $i$-th genotype $(1, \ldots, 3) ; H_{j}$ the fixed effect of the $j$-th herd $(1, \ldots, 4) ; b$ the linear regression coefficient of analyzed trait on calving interval, $x_{i j k}$ calving interval of cow, $\mathrm{Cl}$ the average of calving interval and $e_{i j k}$ the random error.

\section{Results and discussion}

As previously reported (EDRISS et al. 2008) the genotypic frequencies were 0.031 for $A A$, 0.519 for $B B$ and 0.450 for $A B$ as followed by 0.256 for $A$ allele and 0.744 for $B$ allele which were in linkage disequilibrium. Birth weight in BB genotype $(41.98 \mathrm{~kg})$ was significantly 


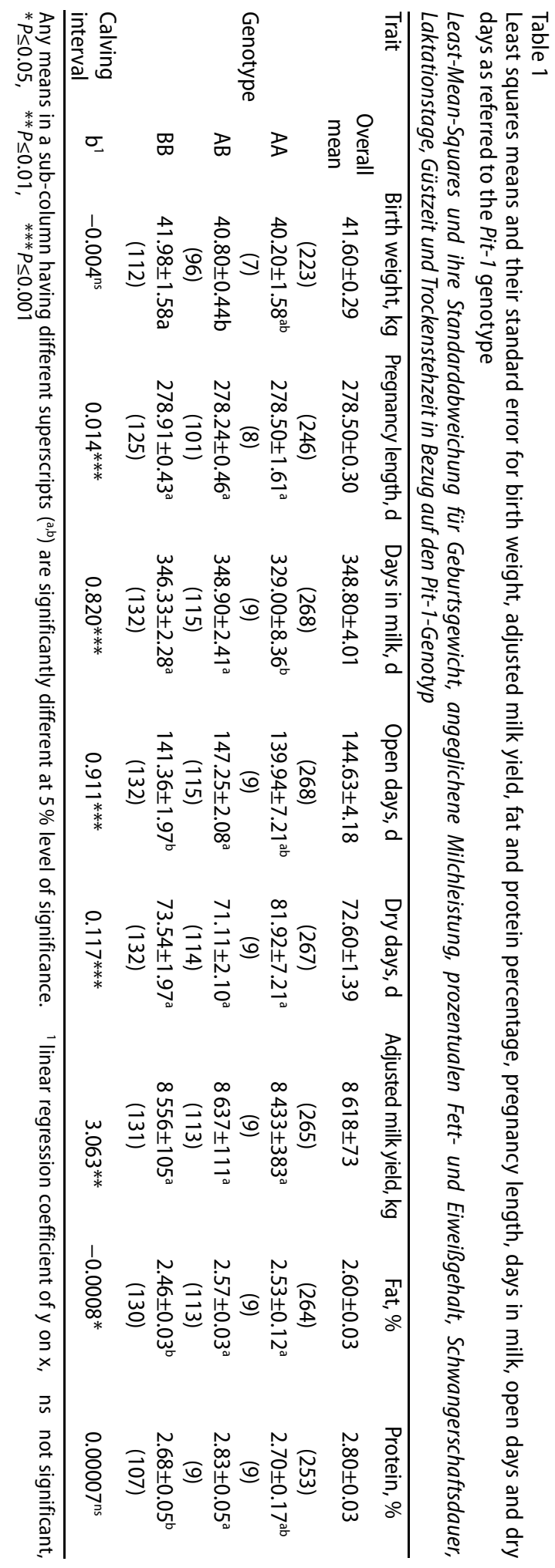


$(P \leq 0.05)$ higher than $A B(40.80 \mathrm{~kg})$ genotype. Adjusted milk yield $(305 \mathrm{~d}, 2 \times)$ were not significantly different among genotypes. Although numerically those individuals carrying $A B$ genotype had produced more milk compare to the other two genotypes. Fat percentage in $A B$ and $A A$ genotypes was significantly $(P \leq 0.05)$ higher than $B B$ genotype. Protein percentage in $A B$ genotype was significantly higher than $B B$ genotype ( $2.83 \%$ vs. 2.68\%). RENAVILLE et al. (1997) showed a superior effect of allele $A$ on milk production $(173.6 \pm 44.6 \mathrm{~kg} ; P \leq 0.1)$ and protein yield $(2.93 \pm 1.45 \mathrm{~kg} ; P \leq 0.05)$, while they reported superiority of $B$ allele over $A$ allele for fat percentage $(20.038 \pm 0.018 \% ; P \leq 0.1)$. Pregnancy length and dry days were not affected by genotype. Days in milk in $A B$ and $B B$ genotypes were significantly $(P \leq 0.05)$ greater than $A A$ genotype $(348,346$ vs. 329 days). Open days in $A B$ genotype was significantly $(P \leq 0.05)$ higher ( +5.89 days) than $B B$ genotype.

\section{References}

Dierkes B, Kriegesmann B, Baumgartner BG, Brening B (1998) Partial genomic structure of the bovine PIT1 gene and characterization of a HinfI transition polymorphism in exon 6. Anim Genet 29, 405

Dybus A, Kmieć M, Sobek Z, Pietrzyk W, Wiśniewski B (2003) Associations between polymorphism of growth hormone releasing hormone $(G H R H)$ and pituitary transcription factor 1 (PIT1) genes and production traits of Limousine cattle. Arch Tierz 46, 527-34

Dybus A, Szatkowska I, Czerniawska-Piątkowska E, Grzesiak W, Wójcik J, Rzewucka E, Zych S (2004) PIT1Hinfl gene polymorphism and its associations with milk production traits in polish Black-and-White cattle. Arch Tierz 47, 557-63

Edriss V, Edriss MA, Rahmani HR, Sayed-Tabatabaei BE (2008) Pit-1 gene polymorphism of Holstein cows in Isfahan province. Biotechnol 7, 209-12

Renaville R, Gengler N, Vrech E, Prandi A, Massart S, Corradini C, Bertozzi C, Mortiaux F, Burny A, Portetelle D (1997) PIT-1 gene polymorphism milk yield and conformation traits for Italian Holstein-Friesian bulls. J Dairy Sci 80, 3431-8

SAS (2003) User's Guide Statistics Version 9.1 Edition 2003. SAS Inst Inc Cary, NC

Received 1 November 2008, accepted 5 June 2009.

Corresponding author

Prof. Dr. MOHAMMAD ALI EDRISS

email: edriss@cc.iut.ac.ir

Department of Animal Science, College of Agriculture, Isfahan University of Technology, Isfahan, Iran, 84156-83111 or on sabbatical leave: Division Genetics and Genomics, Roslin Institute, University of Edinburgh, Midlothian EH25 9PS, Roslin Biocentre, Roslin, Scotland, United Kingdom 